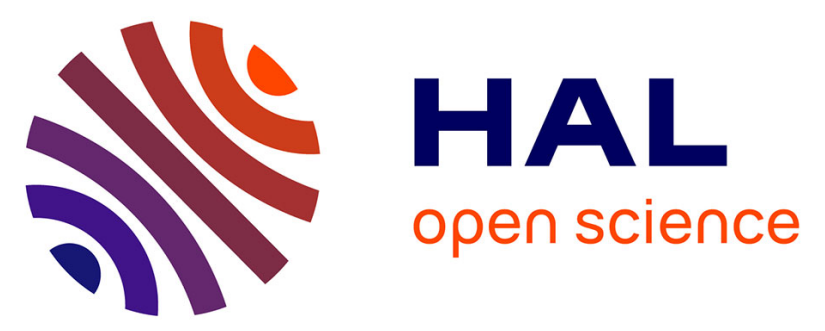

\title{
Electrosynthesis of Pyrenediones on Carbon Nanotube Electrodes for Efficient Electron Transfer with FAD-dependent Glucose Dehydrogenase in Biofuel Cell Anodes
}

Pierre-Yves Blanchard, Paulo Henrique M. Buzzetti, Bridget Davies, Yannig Nedellec, Emerson Marcelo Girotto, Andrew Gross, Alan Le Goff, Yuta Nishina, Serge Cosnier, Michael Holzinger

\section{- To cite this version:}

Pierre-Yves Blanchard, Paulo Henrique M. Buzzetti, Bridget Davies, Yannig Nedellec, Emerson Marcelo Girotto, et al.. Electrosynthesis of Pyrenediones on Carbon Nanotube Electrodes for Efficient Electron Transfer with FAD-dependent Glucose Dehydrogenase in Biofuel Cell Anodes. ChemElectroChem, 2019, 6 (20), pp.5242-5247. 10.1002/celc.201901666 . hal-02389145

HAL Id: hal-02389145

https://hal.science/hal-02389145

Submitted on 18 Nov 2020

HAL is a multi-disciplinary open access archive for the deposit and dissemination of scientific research documents, whether they are published or not. The documents may come from teaching and research institutions in France or abroad, or from public or private research centers.
L'archive ouverte pluridisciplinaire HAL, est destinée au dépôt et à la diffusion de documents scientifiques de niveau recherche, publiés ou non, émanant des établissements d'enseignement et de recherche français ou étrangers, des laboratoires publics ou privés. 


\title{
Electrosynthesis of pyrenediones on carbon nanotube electrodes for efficient electron transfer with FAD dependent glucose dehydrogenase in biofuel cell anodes
}

\author{
Pierre-Yves Blanchard,[a] Paulo Henrique M. Buzzetti,[a] [b] Bridget Davies,[a] Yannig Nedellec,[a] \\ Emerson Marcelo Girotto,[c] Andrew J. Gross,[a] Alan Le Goff,[a] Yuta Nishina, [c] Serge Cosnier,[a] \\ and Michael Holzinger*[a]
}

\begin{abstract}
A particularly efficient redox mediator for electron transfer between FAD dependent glucose dehydrogenase (FAD-GDH) and carbon nanotube (CNT) based electrodes can be obtained via electrosynthetic oxidation of pyrene in aqueous buffer solution. 1H-NMR spectroscopic studies reveal the formation of a 2:1 mixture of 1,6-pyrenedione and 1,8-pyrenedione at the electrode.The formed pyrenedione exhibits a well-defined surface-bound redox system at $-0.1 \mathrm{~V}$ vs. SCE and provides excellent electron transfer kinetics with this enzyme. Furthermore, the $\pi$-system of pyrenedione allows improved stacking behavior with the CNT walls, leading to enhanced stabilities compared to commonly used mediators like naphthoquinone. The electrosynthesis of pyrenedione for catalytic glucose oxidation is optimal at $\mathrm{pH} 2$ using cyclic voltammetry or chronoamerometry. It is envisaged that the electrosynthetic methodology can be expanded to form different redox mediators for a series of enzymes.
\end{abstract}

\section{Introduction}

Enzymatic glucose biofuel cells have gained wide attention due to the possibility to harvest energy out of complex media like body liquids [1] or soft drinks. [2] A further advantage is the eco-friendly character of such power generators for low power consuming disposable devices. [3] The challenge for such biological catalysts is to transfer the electrons involved in the catalytic oxidation process to an electrode. Fungal glucose oxidase (GOx) and FAD dependent glucose dehydrogenases (FAD-GDH) are two of the mostly used glucose oxidizing enzymes [4]. However, achieving electron transfer between their catalytic centers and an electrode is quite difficult, but not impossible, since their active sites are deeply buried inside the insulating protein [5]. In this case, electron shuttles, called redox mediators have to be employed, even when a loss of the final cell voltage has to be taken into account. There are many examples of efficient redox mediators for electron transfers with good compromises between electron transfer kinetics at acceptable overpotentials. [6] They are mostly based on quinone derivatives [4] or redox tunable Osmium complexes [6-7]. Beside the optimization of electrocatalyic currents and open circuit potential (OCPs), the stability of operational mediator-enzyme assembly is an important criterion for enzymatic glucose biofuel cell research since the operational lifetime of such power generators is the principal drawback for realistic applications.

Pyrene and its derivatives have become prominent for the reliable non-covalent functionalization of carbon nanotubes (CNTs) [8]. They have gained interest for the immobilization of biomolecules on sp2 nanocarbon electrodes, principally for biosensing applications [9]. Pyrene itself has no particular electrochemical signature over a wide potential range. However, it can be electropolymerized at $1 \mathrm{~V}$ vs. saturated calomel reference electrode (SCE) in organic solvents like acetonitrile, leading to the appearance of a reversible redox system at $\mathrm{E}^{1 / 2}$ $=0.43 \mathrm{~V}$ vs. $\mathrm{Ag} / \mathrm{AgCl}$ that corresponds to a reinforced poly- (oligo-) pyrene layer on carbon nanotube surfaces [10]. Oxidation of pyrene and other aromatic hydrocarbons by photo- or electrochemistry became an efficient method for remediation and depollution of contaminated soils [11]. Barathi et al. [12] electro-oxidized pyrene in phosphate buffer ( $\mathrm{pH} 7$ ) and used the formed oxides to immobilize cytochrome $\mathrm{c}$ via copper coordination to construct a hydrogen peroxide biosensor. The authors proposed the formation of 4,5,9,10 pyrenetetrone after electrosynthesis based on the observed coordination capacities and by mass spectrometry.

Targeted synthesis routes have been developed to obtain pyrenediones and -tetrones since they are interesting intermediates for the synthesis of polycyclic compounds. In these cases, the isolated products were comprehensively characterized [13]. Furthermore, pyrene oxides provide an interesting negative redox potential at $-0.1 \mathrm{~V}$ vs. SCE at $\mathrm{pH} 7$ because it is close to the redox potentials of flavin adenine dinucleotide (FAD) and FAD containing redox enzymes (between $-0.49 \mathrm{~V}$ [14] and $-0.277 \mathrm{~V} \mathrm{[15]).} \mathrm{The} \mathrm{electrontransfer} \mathrm{from} \mathrm{such}$ enzymes to the mediator is thermodynamically favorable when the redox potential of the mediator is slightly higher that the potential of the active center of the enzyme. Thus, we envisaged the possibility to electrosynthesize specific quinones for mediated electron transfer with flavin adenine dinucleotide FAD dependent enzymes. We evaluated this approach using FAD-GDH in a glucose bioanode setup and were able to isolate the pyrene derivatives to determine their chemical structure with 1H-NMR spectroscopy.

Results and Discussion

Electrosynthesis and characterization of pyrenediones 
The carbon nanotube - pyrene modified electrodes, prepared as described in the experimental section, were placed in phosphate buffer solution $(0.2 \mathrm{molL}-1)$ at different $\mathrm{pH}$ values. The electro-oxidation of pyrene was done by recording cyclic voltammograms between initial potentials of $-0.2 \mathrm{~V},-0.5 \mathrm{~V},-1.0 \mathrm{~V}$ and a switching potential of $1.2 \mathrm{~V}$ for $\mathrm{pH} 2,7$, and 12 , respectively, at a scan rate of $100 \mathrm{mVs}-1$. Figure $1 \mathrm{~A}-\mathrm{C}$ shows the evolution of the reversible redox waves at different $\mathrm{pH}$ values during 15 cycles corresponding to the two-electron transfer process of pyrenedione, as revealed in Section 2. The irreversible oxidation at around $1 \mathrm{~V}$ vs. SCE, corresponding to a definite amount of pyrene, decreases after each cycle. On the second and subsequent scans, a new redox species with reversible behavior is formed with $\mathrm{E}^{1 / 2}=0.17 \mathrm{~V}$ at $\mathrm{pH} 2$ (Figure $1 \mathrm{~A}$ ), $\mathrm{E}^{1 / 2}=-0.09 \mathrm{~V}$ at $\mathrm{pH} 7$ (Figure $1 \mathrm{~B}$ ), and $\mathrm{E}^{1 / 2}=-0.37 \mathrm{~V}$ at $\mathrm{pH} 12$ (Figure 1C) vs. SCE. The peak currents and the charge under the oxidation and reduction peaks are clearly higher after 15 scans of electro-oxidation at $\mathrm{pH} 2$ than at $\mathrm{pH} 7$ and $\mathrm{pH} 12$. The improved yield of electro-oxidized species by electro-oxidation at acidic $\mathrm{pH}$ reflects a proton assisted pyrene oxidation process. This was quantitatively confirmed by calculating the electroactive surface coverage, $\square$, by integration of the anodic peak area to give the transferred charges, $\mathrm{Q}$, according to the formula:

$\square \square \square \square \frac{\mathrm{Q}}{n F A}$.

Where $\mathrm{n}$ is the number of involved electrons, $\mathrm{F}$ is the Faraday constant, and $\mathrm{A}$ is the geometric surface area. For an identic amount of deposited pyrene, when electro-oxidized at $\mathrm{pH} 2$, a surface coverage of

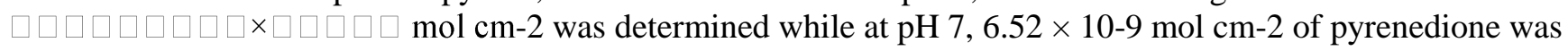
formed. The redox peaks correspond to the two-electron transfer process of pyrenedione, as revealed in Section 2 . Figure 1: Cyclic voltammograms showing the electrosynthesis of pyrene quinone at $\mathrm{A}$ ) $\mathrm{pH} \mathrm{2,} \mathrm{B)} \mathrm{pH}$, and $\mathrm{C} \mathrm{pH}$ 12. D) cyclic voltammograms of the obtained product in fresh phosphate buffer $(0.1 \mathrm{molL}-1, \mathrm{pH} 7)$ at different
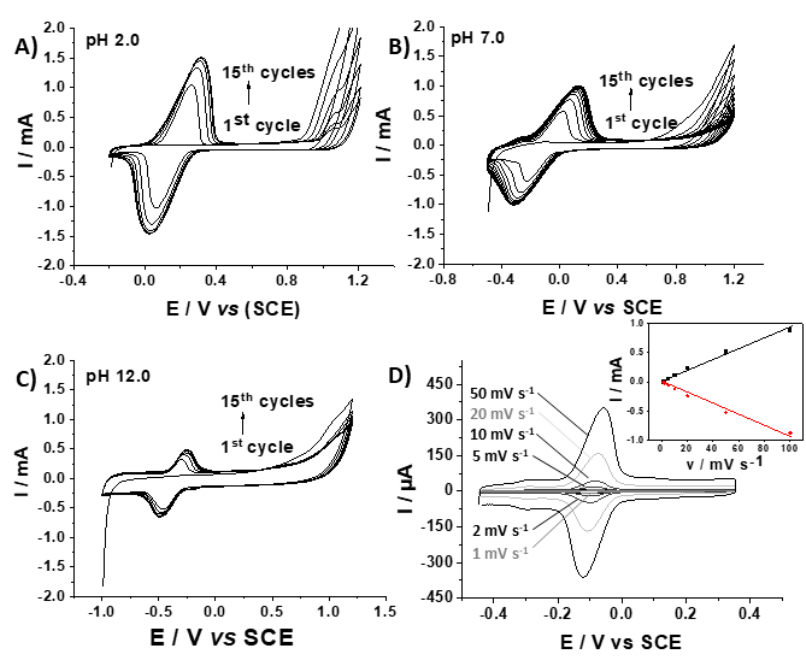

scan rates from 5 to $50 \mathrm{mV} \mathrm{s}-1$ and (inset) plot of the anodic and cathodic peak currents at varying scan rates.

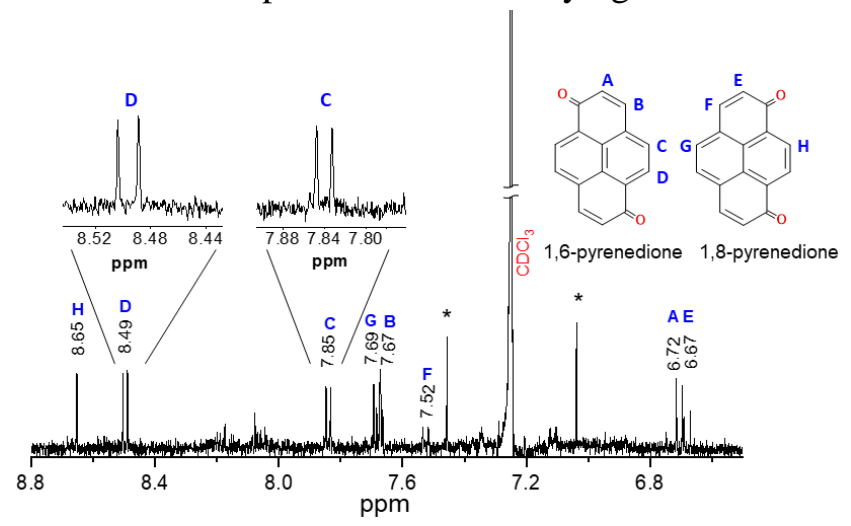

The modified electrodes were characterized by cyclic voltammetry in fresh buffer solution at $\mathrm{pH} 7$ in the range

between -0.4 and $0.4 \mathrm{~V}$ vs. SCE at different scan rates (Figure 1D) with scan rates varying from 5 to $50 \mathrm{mVs}-1$. By plotting the maximum currents as a function of the scan rate, a linear dependency is observed, confirming that the electro-oxidized species remains immobilized (inset, Figure 1D). Pyrene functionalization of carbon nanotubes became prominent in the literature because of the stable $\pi$-stacking interactions between their aromatic structures. The electro-oxidation of pyrene, disturbing its $\pi$ system, seems not to affect the stability of these interactions.

It should be noted that the presence of carbon nanotubes is necessary for the later use of electrosynthesized pyrenediones. Cyclic voltammetric, or amperometric pyrene electro-oxidation using standard glassy carbon electrodes (GCE) led to non-conclusive results, most likely related to the desorption of oxidized pyrene.

\section{Characterization by 1H-NMR spectroscopy}

In order to get more insight into which type of pyrenediones was formed, the electro-oxidized pyrene-MWCNT deposits were removed from 8 different modified electrodes. These deposits were subsequently immersed in 0.75 $\mathrm{mL} \mathrm{CDCl} 3$ to desorb the formed pyrenedioness from the MWCNTs. After centrifugation, the supernatant that was free of solids was used for the 1NMR studies.

Figure 2 shows the measured features between 6.6 and $8.8 \mathrm{ppm}$. By referring to comprehensively characterized pyrenediones derivatives in the literature [13], a mixture of 1,6-pyrenedione and 1,8-pyrenedione can be identified. 1,8-pyrenedione shows a characteristic singlet $(2 \mathrm{H}$, protons $\mathrm{H})$ at $8.65 \mathrm{ppm}$. Two doublets are assigned to protons $\mathrm{D}$ and $\mathrm{C}$ of 1,6-pyrenedione at 8.49 and $7.85 \mathrm{ppm}$, respectively. By integration of the peaks $\mathrm{H}$ and $\mathrm{D}$, a ratio of the electrosynthesized 1,6-pyrenedione and 1,8-pyrenedione of 2:1 can be determined. It should be noted 
that no characteristic peak of 4,5-pyrenedione or 4,5,9,10-pyrenetetrone, or any other pyrene quinones [16], could be resolved [13a].

Figure 2: 1H-NMR spectrum of the extracted pyrenediones derivatives with zoom on the doublets $\mathrm{D}$ and $\mathrm{C}(*=$ 13C satellite peaks).

The detailed assignments of the peaks:

1,6-pyrenedione

1H NMR (300 MHz, CDCl3) $\delta 6.72(\mathrm{~d}, 2 \mathrm{H}, \mathrm{J}=7.96 \mathrm{~Hz}, \mathrm{HA}), \delta 7.67(\mathrm{~d}, 2 \mathrm{H}, \mathrm{J}=8.80 \mathrm{~Hz}, \mathrm{HB}), \delta 7.85(\mathrm{~d}, 2 \mathrm{H}, \mathrm{J}=$ $6.03 \mathrm{~Hz}, \mathrm{HC}), \delta 8.49(\mathrm{~d}, 2 \mathrm{H}, \mathrm{J}=5.83 \mathrm{~Hz}, \mathrm{HD})$.

1,8-pyrenedione

1H NMR (300 MHz, CDCl3) $\delta 6.67(\mathrm{~d}, 2 \mathrm{H}, \mathrm{J}=7.88 \mathrm{~Hz}, \mathrm{HE}), \delta 7.52(\mathrm{~d}, 2 \mathrm{H}, \mathrm{J}=6.80 \mathrm{~Hz}, \mathrm{HF}), \delta 7.69(\mathrm{~d}, 2 \mathrm{H}, \mathrm{J}=$ $7.76 \mathrm{~Hz}, \mathrm{HG}), \delta 8.65(\mathrm{~d}, 2 \mathrm{H}, \mathrm{J}=0.80 \mathrm{~Hz}, \mathrm{HH})$.
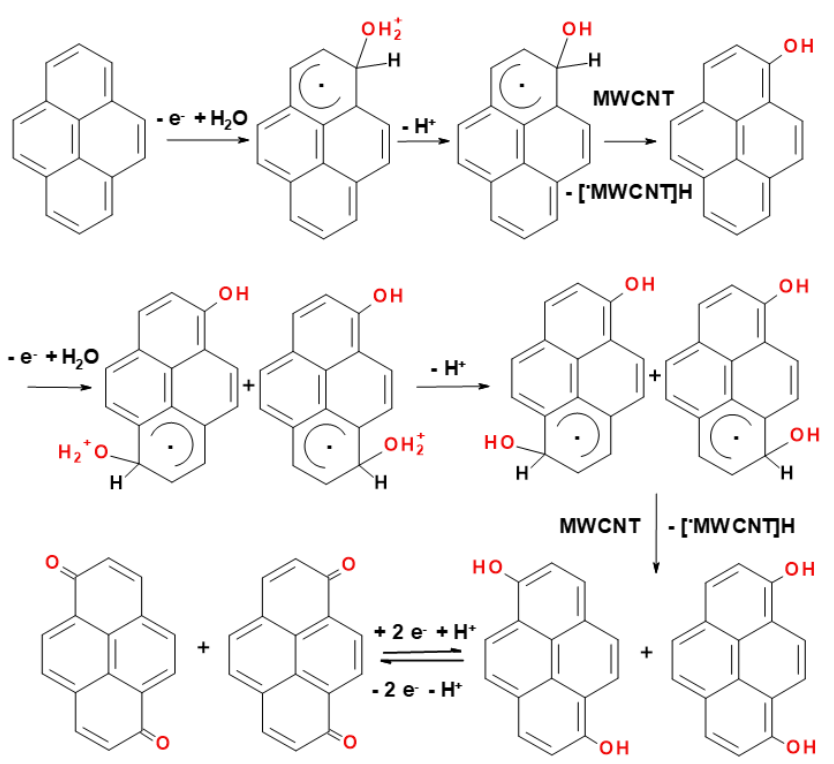

Scheme 1: Proposed mechanism for the electrooxidation of pyrene at carbon nanotubes in acidic and basic aqueous buffer solution.

Based on these ratios and the $\mathrm{pH}$ effect, a mechanism for the electro oxidation of pyrene in buffer solution can be proposed according to the mechanism of the oxidative photolysis of pyrene in water [11b]. The first oxidation step initially forms a radical which is trapped by a water molecule while the positively polarized MWCNTs serve as a radical scavenger [17], leading to 1-hydroxy pyrene. The formation of a defect on the MWCN

$\mathrm{T}$ wall is accepted since the outer wall is already highly
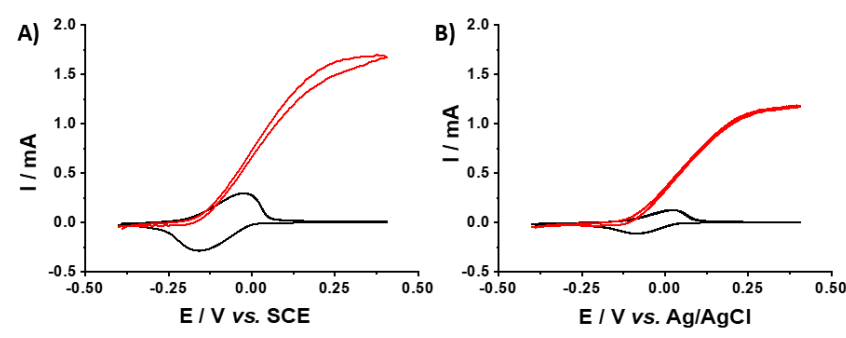

defective. The second oxidation step occurs in either the 6 or the 8 position, where the formed aromatic radicals are again trapped by water and scavenged by the MWCNT electrode giving the 1,6- and 1,8-dihydroxy pyrene derivative and water in the overall redox equation. These dihydroxy pyrenes may then be reversibly oxidized in a two electron process by cyclic voltammetry, as observed in Figure 1 . The intermittent formation of $\mathrm{H}+$ ions is more effective under acidic conditions, supporting the improved electro synthesis of pyrenediones at $\mathrm{pH} 2$. Figure $\mathrm{S} 1$ in the supporting information shows the $\mathrm{pH}$ dependency of this redox system which is characteristic for quinones. A more interesting point concerns the position where water is added in the second oxidation step. It seems that the pyrene intermediates are better stabilized if they can keep intact their naphthalene units, obeying Hückel's law, rather than forming phenanthrene units when water traps the radical in the ortho-position. This explains the absence of 4,5 pyrenedione in the extracted solutions. Furthermore, the two electro-oxidation steps at two different positions most likely occur almost simultaneously since no traces of monohydroxy pyrene could be isolated, in contrast to Sigman et al. [11b]. Compared to similar experiments in dry organic solvents, there is no water to trap the formed radicals and induces the polymerization process with other pyrene molecules instead of the described water addition reaction.

Evaluation of pyrenedione for mediated electron transfer with FAD-GDH for catalytic glucose oxidation

The onset potential at $\mathrm{pH} 7$ of around $-0.1 \mathrm{~V}$ of pyrenedione is in the optimal range for mediated electron transfer with FAD dependent glucose oxidizing enzymes like glucose oxidase or FAD-GDH. We used FAD-GDH from Aspergillus sp for the experiments concerning the wiring efficiency of pyrenedione. The bioelectrodes were prepared by drop-casting $40 \mu \mathrm{L}$ of a $5 \mathrm{mg} \mathrm{mL}-1$ enzyme solution onto the modified electrodes and incubating the electrodes for $2 \mathrm{~h}$ at $3{ }^{\circ} \mathrm{C}$. After rinsing with phosphate buffer solution (0.1 molL-1, pH 7), cyclic voltammograms were recorded in the presence and absence of $200 \mathrm{mmol} \mathrm{L}-1$ glucose at $\mathrm{pH}$. Figure 3 shows the voltammetric behaviour of the bioelectrodes prepared using pyrenediones initially electro-oxidized at $\mathrm{pH} 2$ (Figure 3A) and at $\mathrm{pH} 7$ (Figure 3B). In both cases, in the presence of glucose, a drastic increase in current signal with a sigmoidal wave is observed at $20 \mathrm{mV} \mathrm{s}-1$ consistent with effective electrocatalytic oxidation of glucose mediated by the pyrenedione molecules. When pyrene was electro-oxidized at $\mathrm{pH} 2$, the maximum current 
obtained of $1.7 \mathrm{~mA}(8.51 \mathrm{~mA} \mathrm{~cm}-2)$ is more than $40 \%$ higher than that for the pyrenedione electro-oxidized at $\mathrm{pH}$ $7\left(1.18 \mathrm{~mA}, 5.93 \mathrm{~mA} \mathrm{~cm}^{2}\right)$. This reflects the improved electro-oxidation yield for the electroactive mediator at lower $\mathrm{pH}$.

Evaluation of the steady-state current at a fixed potential of $0.2 \mathrm{~V}$ vs. SCE as a function of glucose concentration revealed a linear increase between $1 \mathrm{mmol} \mathrm{L}-1$ and $30 \mathrm{mmol} \mathrm{L}-1$. The current increases with increasing concentration up to a maximum of $1.2 \mathrm{~mA}$, or $13.5 \mathrm{~mA} \mathrm{~cm}-2$ at $100 \mathrm{mmol} \mathrm{L}-1$ for the pyrenedione electrode prepared at $\mathrm{pH} 2$ (Figure S2). It is noted that the maximum current performance is almost reached at $50 \mathrm{mmol} \mathrm{L-}$ 1. The data in Figure S2 shows that the linear range matches perfectly with the required detection range of commercialized glucose biosensors. Further data including the apparent Michaelis Menten constant and sensitivity are available in the supporting information.

Figure 3: cyclic voltammograms of electrocatalytic glucose oxidation using FAD-GDH modified pyreneMWCNT electrodes formed by electro-oxidation of pyrene at A) $\mathrm{pH} 2$ and $\mathrm{B}$ ) $\mathrm{pH} 7$. The cyclic voltammograms were recorded in phosphate buffer $(0.1 \mathrm{~mol} \mathrm{~L}-1, \mathrm{pH} 7)$ in the absence (black) and presence (grey) of $200 \mathrm{mmol} \mathrm{L}$ 1 glucose at a scan rate of $20 \mathrm{mV} \mathrm{s}-1$

Comparison of the wiring performances for catalytic glucose oxidation with 1,4 naphthoquinone.

Naphthoquinone is one of the most commonly used quinone based mediators for the enzymatic bioanodes of glucose biofuel cells [18]. This is why this type of quinone was chosen as a reference mediator to evaluate the appropriateness of electrosynthesized pyrenedione for efficient electron transfer with FAD-GDH. Figure 4A shows an overlay of the cyclic voltammograms of pyrene quinone and 1,4 naphthoquinone modified MWCNT electrodes recorded in 0.1 molL-1 phosphate buffer $\mathrm{pH} 7$ in the presence and absence of $200 \mathrm{mmol} \mathrm{L-1}$ glucose. With 1,4 naphthoquinone as the mediator, in the absence of glucose, the well-known redox system around -0.15 $\mathrm{V}$ vs. SCE with an onset potential of $-0.2 \mathrm{~V}$ is observed. In presence of glucose, a catalytic current density is observed reaching up to $3.3 \mathrm{~mA} \mathrm{~cm}^{-2}$ at $0.2 \mathrm{~V}$. The redox wave at $-0.036 \mathrm{~V}$ ) with an onset potential of $-0.1 \mathrm{~V}$ for pyrenedione is slightly more positive but leads to clearly higher current densities up to $19 \mathrm{~mA} \mathrm{~cm}^{2}$ at $0.2 \mathrm{~V}$. It has to be noted that the comparison was made using electrodes with identic surface coverages of electroactive species and by drop-casting the same amount of enzyme Figure 4B compares the recorded catalytic currents at $0.2 \mathrm{~V}$, obtained from cyclic voltammograms, for each mediator as a function of the surface coverage.
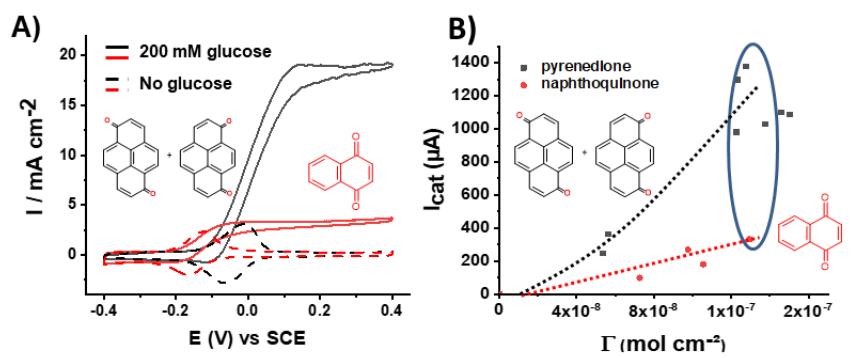
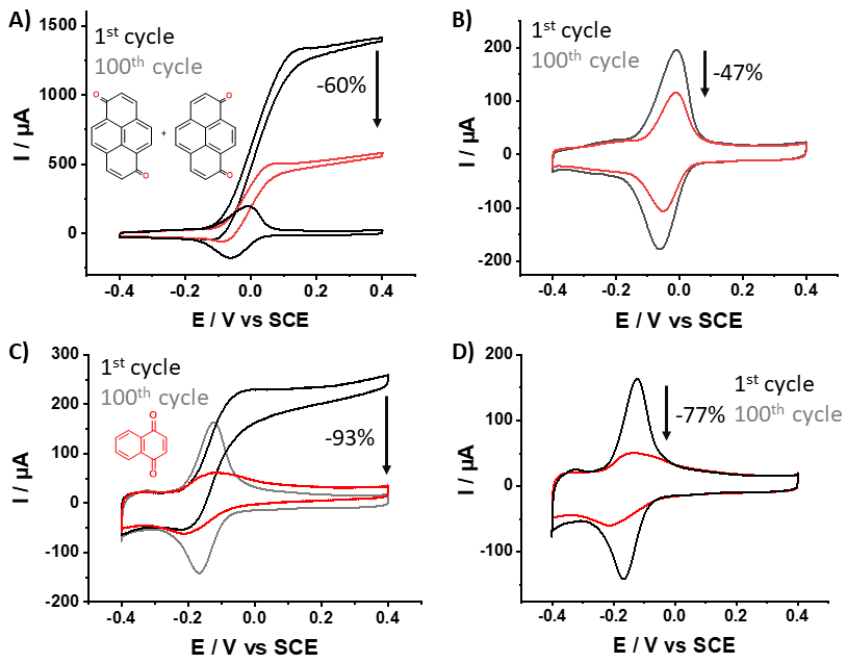

pyrenedione clearly provides higher efficiency for the mediated electron transfer with FAD-GDH.

Figure 4: A) Cyclic voltammograms of FAD-GDH modified MWCNT electrodes including (black) pyrenedione and (grey) 1,4 naphthoquinone in the absence (dashed lines) and the presence (straight line) of $200 \mathrm{mmol} \mathrm{L-1}$ glucose at $\mathrm{pH}$ 7. B) Recorded catalytic currents at $0.2 \mathrm{~V}$ vs SCE as a function of the surface coverage of the mediator (black: pyrenedione; grey: 1,4 naphthoquinone)

This clear superiority of pyrenedione for mediated electron transfer with FAD-GDH and acceptable low overpotentials was further investigated in terms of stability. Again, cyclic voltammetry was used for this study. Figure 5A shows the first and hundredth cyclic voltammograms recorded for pyrenequinone mediated FAD-GDH bioanodes at 200 mmolL-1 glucose between $-0 ; 4 \mathrm{~V}$ and $0.4 \mathrm{~V}$ vs. SCE.. The electrocatalytic performance decreased such that about $60 \%$ of the catalytic current was lost after 100 cycles. In the case of 1,4 naphthoquinone, a loss of more than $90 \%$ was observed after 100 cycles (Figure 5C). The performance losses are generally explained by parasitic parallel reactions that reduces the reversibility of the redox system of quinoic mediators [19]. This is further accentuated with the higher water solubility of naphthohydroquinone compared to pyrenehydroquinone, the reduced forms of the mediators, leading to loss of the mediator in solution. Control experiments recorded with the same electrodes in the absence of glucose show that $47 \%$ of the quinone activity 
is lost for the pyrenedione electrode after the intense treatment of 100 cycles while the naphthoquinone bioelectrodes lost $77 \%$ of its redox activity. This experiment allows us to conclude that about $15 \%$ of the performance loss for both bioelectrodes is related to the decrease of the enzyme activity or enzyme desorption. The pyrenedione bioelectrode showed clearly better cycling stability compared to the naphthoquinone bioelectrode highlighting improved robustness for the electro-oxidised electrode. It has to be noted that that these cyclovoltammetric experiments have to be seen as accelerated aging tests. We studied performance losses over time using glucose oxidase and naphthoquinone where we observed an $80 \%$ decrease of produced power after one-year storage in buffer solution and non-continuous discharges. [20]

Figure 5: First and hundredth cyclic voltammogram of pyrenedione and 1,4 naphthoquinone mediated FAD-GDH bioelectrodes -0.4 and $0.4 \mathrm{~V}$ at $\mathrm{pH} 7$ (scan rate $20 \mathrm{mVs}-1$ ). A) pyrenedione electrode in $200 \mathrm{mmolL}-1$ glucose. B) pyrenedione bioelectrode without glucose. C) 1,4 naphthoquinone bioelectrode in 200 mmol L-1 glucose. D) 1,4 naphthoquinone bioelectrode without glucose.

Performances of the bioanode in a glucose/oxygen biofuel cell setup

Finally, the studied bioanodes were assembled with a biocathode operating with direct electron transfer between proptoporphyrin IX modified MWCNTs and bilirubin oxidase (BOD) [21]. The bioelectrodes were placed in an electrochemical cell containing $200 \mathrm{mmol} \mathrm{L}-1$ glucose in oxygen saturated buffer solution

Figure 6A shows the obtained power profile of the resulting glucose biofuel cell. All data points were recorded after $30 \mathrm{~s}$ discharge to eliminate the capacitive current. A maximum power density of $1.35 \mathrm{~mW} \mathrm{~cm}-2$, calculated using the geometric surface area of $0.07 \mathrm{~cm}^{2}$, could be determined with an OCV at $0.69 \mathrm{~V}$. Figure $6 \mathrm{~B}$ demonstrate the performance of this bioanode and its contribution on this power output regarding the limiting performances of the biocathode.

Figure 6: A) Power profile (grey) and voltage dependent evolution of the maximum current densities (black) of the constructed glucose biofuel cell in in oxygen saturated phosphate buffer $(0.1 \mathrm{~mol} \mathrm{L-1,} \mathrm{pH} 7)$. The current
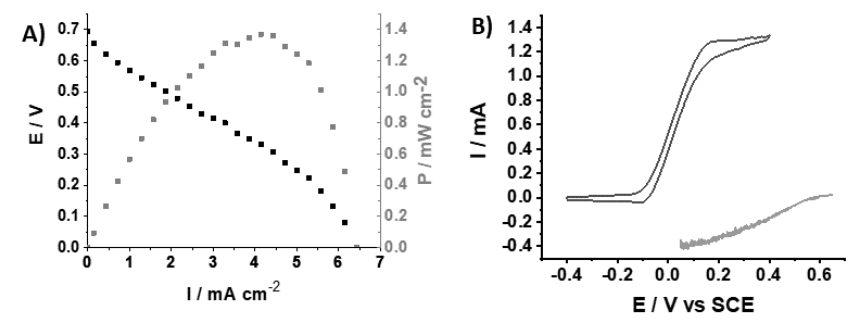
densities were recorded after $30 \mathrm{~s}$ discharge at given potentials. B) Bioelectrocatalytic performances of the bioanode with pyrenedione mediator (black) and the BOD-protoporphyrin IX based biocathode (grey) in oxygen saturated phosphate buffer solution $(0.1$ mmolL-1, pH 7) containing $200 \mathrm{mmol} \mathrm{L-1} \mathrm{glucose} \mathrm{at}$ $20 \mathrm{mV} \mathrm{s}-1$.

Conclusion

The electro-oxydation of pyrene forms an efficient mediator for FAD GDH which surpasses currently used mediators like naphthoquinone in terms of electrocatalytic current densities and stability. Contrary to Barathi et al. [12], we determined the formation of a 2:1 mixture of 1,6-pyrenedione and 1,8-pyrenedione with 1H NMR spectroscopy via pyrene electro-oxidation in aqueous conditions. This approach opens up new possibilities in terms of the electrosynthesis of redox mediators from polyaromatic precursors. The oxidation of pyrene and other polyaromatic molecules is furthermore of interest for remediation and transformation into useful products. The easy synthesis procedure, electron transfer efficiency, stability, and potential to make a wide range of redox mediators makes the aqueous electrosynthesis approach a real alternative to other quinone or Os complex based redox mediators.

Experimental Section

Glassy carbon electrodes ( $3 \mathrm{~mm}$ diameter) were functionalized in several steps. First, MWCNTs were dispersed in NMP ( $5 \mathrm{mg} \mathrm{mL}-1)$ by sonication until a homogeneous black suspension was obtained. $20 \mu \mathrm{L}$ of the MWCNT suspension was then deposited on the electrode to obtain a $5 \mu \mathrm{m}$ - thick film. After drying, the MWCNT deposits were modified with pyrene by drop casting $20 \mu \mathrm{L}$ of a $10 \mathrm{mmol} \mathrm{L}-1 \mathrm{CH} 2 \mathrm{Cl} 2$ pyrene solution. After an incubation/evaporation time over $10 \mathrm{~min}$ at room temperature in a fume hood, the electrodes were rinsed several times with $\mathrm{H} 2 \mathrm{O}$ and then dried and stored at $5^{\circ} \mathrm{C}$ until use. Naphthoquinone modified MWCNT electrodes were prepared correspondingly.

The bioanodes were formed as described in [21] by dropcasting of $20 \mu \mathrm{L}$ of a 3mmolL-1 DMF solution of protoporphyrin IX on MWCNT electrodes. After drying, the electrodes were rinsed with acetonitrile. Finally, 20 $\mu \mathrm{L}$ of a $5 \mathrm{mg} \mathrm{mL}-1$ phosphate buffer $(0.1 \mathrm{molL}-1, \mathrm{pH}$ 7) solution of BOD from Myrothecium verrucaria is deposit and dried at $5^{\circ} \mathrm{C}$.

Acknowledgements

The authors wish to acknowledge the support from the platform Chimie NanoBio ICMG FR 2607 (PCN-ICMG) and from the LabEx ARCANE (ANR-11-LABX-0003-01 and CBH-EUR-GS, ANR-17-EURE-0003). The 
authors particularly thank the ANR - JST program, project Mocca-Cell (ANR-15-JTIC-0002-01), and the Institut Carnot PolyNat (CARN 0007-01) for financial support. E.M.G. thanks CNPq for the grants.

Keywords: Carbon nanotubes $\bullet$ electron transfer $\bullet$ molecular electrochemistry $\bullet$ FAD dependent glucose dehydrogenase $\bullet$ Glucose bioanodes

[1] B. Shi, Z. Li, Y. Fan, Advanced Materials 2018, 30, 1801511.

[2] Y. Yu, Y. Han, B. Lou, L. Zhang, L. Han, S. Dong, Chemical Communications 2016, 52, 13499-13502.

[3] C. Abreu, Y. Nedellec, O. Ondel, F. Buret, S. Cosnier, A. Le Goff, M. Holzinger, Sens. Actuator B-Chem. 2018, 277, 360-364.

[4] R. D. Milton, D. P. Hickey, S. Abdellaoui, K. Lim, F. Wu, B. Tan, S. D. Minteer, Chem. Sci. 2015, 6, 48674875.

[5] P. N. Bartlett, F. A. Al-Lolage, Journal of Electroanalytical Chemistry 2018, 819, 26-37.

[6] A. Heller, Physical Chemistry Chemical Physics 2004, 6, 209-216.

[7] P. Pinyou, A. Ruff, S. Pöller, S. Ma, R. Ludwig, W. Schuhmann, Chem. Eur. J. 2016, 22, 5319-5326.

[8] R. J. Chen, Y. Zhang, D. Wang, H. Dai, J. Am. Chem. Soc. 2001, 123, 3838-3839.

[9] aZ. Zhu, Nanomicro Lett 2017, 9, 25; bP. Suvarnaphaet, S. Pechprasarn, Sensors (Basel) 2017, 17, 2161; cT. Pasinszki, M. Krebsz, T. T. Tung, D. Losic, Sensors (Basel) 2017, 17, E1919.

[10] R. Haddad, M. Holzinger, R. Villalonga, A. Neumann, J. Roots, A. Maaref, S. Cosnier, Carbon 2011, 49, 2571-2578.

[11]aS. Xu, S. Guo, B. Wu, F. Li, T. Li, Journal of Environmental Sciences 2014, 2014 v.26, pp. 2290-2297; bM. E. Sigman, P. F. Schuler, M. M. Ghosh, R. T. Dabestani, Environmental Science \& Technology 1998, 32, 39803985.

[12] P. Barathi, A. Senthil Kumar, Langmuir 2013, 29, 10617-10623.

[13]aJ. Hu, D. Zhang, F. W. Harris, The Journal of Organic Chemistry 2005, 70, 707-708; bA. López-Moreno, D. Clemente-Tejeda, J. Calbo, A. Naeimi, F. A. Bermejo, E. Ortí, E. M. Pérez, Chemical Communications 2014, 50, 9372-9375.

[14] O. Courjean, F. Gao, N. Mano, Angewandte Chemie International Edition 2009, 48, 5897-5899.

[15] S. Vogt, M. Schneider, H. Schäfer-Eberwein, G. Nöll, Analytical Chemistry 2014, 86, 7530-7535.

[16] P. Boldt, D. Bruhnke, Journal für Praktische Chemie/Chemiker-Zeitung 1994, 336, 110-114.

[17] A. Galano, Nanoscale 2010, 2, 373-380.

[18] B. Reuillard, A. Le Goff, C. Agnes, M. Holzinger, A. Zebda, C. Gondran, K. Elouarzaki, S. Cosnier, Physical Chemistry Chemical Physics 2013, 15, 4892-4896.

[19] aD. P. Tabor, R. Gómez-Bombarelli, L. Tong, R. G. Gordon, M. J. Aziz, A. Aspuru-Guzik, Journal of Materials Chemistry A 2019, 7, 12833-12841; bM. Uchimiya, A. T. Stone, Chemosphere 2009, 77, 451-458. [20] B. Reuillard, C. Abreu, N. Lalaoui, A. Le Goff, M. Holzinger, O. Ondel, F. Buret, S. Cosnier, Bioelectrochem. 2015, 106, 73-76.

[21] N. Lalaoui, A. Le Goff, M. Holzinger, S. Cosnier, Chem. Eur. J. 2015, 21, 16868-16873. 